\title{
Using indirect methods to constrain symbiotic nitrogen fixation rates: a case study from an Amazonian rain forest
}

\author{
Cory C. Cleveland • Benjamin Z. Houlton • \\ Christopher Neill $\cdot$ Sasha C. Reed • \\ Alan R. Townsend $\cdot$ Yingping Wang
}

Received: 4 March 2009/Accepted: 10 November 2009/Published online: 5 December 2009

(C) The Author(s) 2009. This article is published with open access at Springerlink.com

\begin{abstract}
Human activities have profoundly altered the global nitrogen $(\mathrm{N})$ cycle. Increases in anthropogenic $\mathrm{N}$ have had multiple effects on the atmosphere, on terrestrial, freshwater and marine ecosystems, and even on human health. Unfortunately, methodological
\end{abstract}

C. C. Cleveland $(\bowtie) \cdot$ S. C. Reed

Department of Ecosystem and Conservation Sciences,

College of Forestry \& Conservation, University

of Montana, 32 Campus Drive/CHCB 423B,

Missoula, MT 59812, USA

e-mail: cory.cleveland@umontana.edu

\section{B. Z. Houlton}

Department of Land, Air and Water Resources, University of California, 32 Campus Drive/CHCB 423B, Davis, MT 59812, USA

C. Neill

The Ecosystems Center, Marine Biological Laboratory, Woods Hole, MA 02543, USA

S. C. Reed

U.S. Geological Survey, Southwest Biological Science Center, Moab, UT 84532, USA

A. R. Townsend

Department of Ecology and Evolutionary Biology and INSTAAR: An Earth and Environmental Sciences Institute, University of Colorado, Boulder, CO 80303, USA

Y. Wang

CSIRO Marine and Atmospheric Research, Aspendale, VIC 3195, Australia limitations challenge our ability to directly measure natural $\mathrm{N}$ inputs via biological $\mathrm{N}$ fixation $(\mathrm{BNF})$ - the largest natural source of new $\mathrm{N}$ to ecosystems. This confounds efforts to quantify the extent of anthropogenic perturbation to the $\mathrm{N}$ cycle. To address this gap, we used a pair of indirect methods-analytical modeling and $\mathrm{N}$ balance-to generate independent estimates of BNF in a presumed hotspot of $\mathrm{N}$ fixation, a tropical rain forest site in central Rondônia in the Brazilian Amazon Basin. Our objectives were to attempt to constrain symbiotic $\mathrm{N}$ fixation rates in this site using indirect methods, and to assess strengths and weaknesses of this approach by looking for areas of convergence and disagreement between the estimates. This approach yielded two remarkably similar estimates of $\mathrm{N}$ fixation. However, when compared to a previously published bottom-up estimate, our analysis indicated much lower $\mathrm{N}$ inputs via symbiotic BNF in the Rondônia site than has been suggested for the tropics as a whole. This discrepancy may reflect errors associated with extrapolating bottom-up fluxes from plot-scale measures, those resulting from the indirect analyses, and/or the relatively low abundance of legumes at the Rondônia site. While indirect methods have some limitations, we suggest that until the technological challenges of directly measuring $\mathrm{N}$ fixation are overcome, integrated approaches that employ a combination of model-generated and empirically-derived data offer a promising way of constraining $\mathrm{N}$ inputs via $\mathrm{BNF}$ in natural ecosystems. 
Keywords Amazon Basin - Ecosystem modeling · Mass balance $\cdot$ Nitrogen fixation

Nutrient cycling · Rondônia · Tropical forest

\section{Introduction}

How much have human activities altered the global nitrogen $(\mathrm{N})$ cycle? Estimates now suggest that the creation of reactive $\mathrm{N}$ via fossil fuel combustion, fertilizer production and the cultivation of $\mathrm{N}$-fixing crops rivals $\mathrm{N}$ inputs from all natural processes combined (Vitousek et al. 1997; Galloway et al. 2004). The increase in human-derived $\mathrm{N}$ has been implicated in a range of environmental problems including widespread declines in forest health, changes in species diversity and composition, and eutrophication of aquatic ecosystems (Schulze 1989; Vitousek et al. 1997; Galloway et al. 2003). However, the true extent to which human activities have perturbed the global $\mathrm{N}$ cycle is unknown, owing largely to uncertainties in estimates of the amount fixed $\mathrm{N}$ that enters the biosphere via biological $\mathrm{N}$ fixation (BNF).

In natural ecosystems, BNF is the largest potential source of "new" $\mathrm{N}$-entering either through symbiotic relationships (e.g., between legumes and Rhizobia) or by free-living microorganisms. Empirical measurements of natural BNF in terrestrial ecosystems are technically difficult to make. As a result, current estimates remain largely unresolved, limiting our ability to compare anthropogenic versus natural $\mathrm{N}$ inputs. For example, published estimates of terrestrial BNF suggest that it may vary by more than a factor of two within any single biome, and by more than a factor of three (i.e., $80-250 \mathrm{Tg} \mathrm{N}$ year ${ }^{-1}$ ) at the global scale (e.g., Cleveland et al. 1999). This uncertainty undermines efforts to assess human impacts on the global $\mathrm{N}$ cycle, fundamentally challenging the biogeosciences (Vitousek et al. 2002).

Two things in particular limit our ability to accurately quantify BNF. First, we lack a method to directly measure symbiotic $\mathrm{N}$ fixation rates (e.g., Warembourg 1993). High background concentrations of $\mathrm{N}_{2}$ in the atmosphere make it impossible-at least using current technology - to detect small changes in $\mathrm{N}_{2}$ concentration resulting from $\mathrm{N}$ fixation. As a result, rates are most frequently assessed using indirect approaches (e.g., ${ }^{15} \mathrm{~N}$ and ARA) that may or may not provide accurate estimates (Warembourg 1993, Gehring et al. 2005). Second, symbiotic BNF is both spatially and temporally heterogeneous, owing to patchy distributions of potential $\mathrm{N}$-fixers (ter Steege et al. 2006) and phylogenetic constraints to nodulation and $\mathrm{N}$ fixation (Sprent 2005). For example, $\mathrm{N}$ fixation is widespread throughout the Fabaceae, but the predisposition to fix $\mathrm{N}$ is not expressed equally among all sub-families (Sprent and Parsons 2000). In the Caesalpiniaceae subfamily, only $\sim 20 \%$ of the species examined to date appear capable of $\mathrm{N}$ fixation (Allen and Allen 1981; Sprent 2005). Yet, as is the case with most subfamilies, there are numerous genera within the Caesalpiniaceae for which the potential for nodulation has not been well established (Sprent 2005). In addition, even in species with the ability to nodulate, the presence of nodules does not necessarily guarantee $\mathrm{N}$ fixation, making it difficult to infer $\mathrm{N}$ fixation rates from nodule abundance (Cleveland et al. 1999).

Finally, ${ }^{15} \mathrm{~N}$ isotopic methods have been used successfully to assess symbiotic BNF rates in agricultural species growing in monoculture, but they often fail when applied to heterogeneous ecosystems where source ${ }^{15} \mathrm{~N}$ and isotopic fractionations significantly alter $\mathrm{N}$ pools and fluxes (Houlton et al. 2007). As a result of these difficulties our understanding of $\mathrm{N}$ fixation rates in natural ecosystems remains poor. This situation thus begs the question, how do we understand a fundamental ecological process (like $\mathrm{N}$ fixation) when we lack the ability to measure it?

Indirect methods such as simulation modeling and analyses of ecosystem $\mathrm{N}$ balances may offer useful alternative approaches for constraining $\mathrm{N}$ fixation rates at the watershed scale. For example, $\mathrm{N}$ balance approaches have been used to estimate nutrient fluxes in a range of sites and contexts (e.g., Chestnut et al. 1999; Vitousek et al. 2002; Binkley et al. 2004), and models have been used to predict $\mathrm{N}$ fixation as a function of forest succession (Rastetter et al. 2001) and at the global scale (Houlton et al. 2008). Thus, in the absence of methods to directly assess symbiotic $\mathrm{N}$ fixation rates, we suggest that indirect approaches may offer a reasonable way forward for estimating BNF beyond the plot-level scale.

Here, by way of example, we used both synthetic modeling and $\mathrm{N}$ balance approaches to generate 
independent estimates of $\mathrm{BNF}$ at a tropical rain forest site in Rondônia in the Amazon Basin. We focused on a tropical rain forest site for several reasons. First, while tropical rain forests occupy only $\sim 13 \%$ of global land area (Cramer et al. 1999), they represent a hotspot of putative N-fixers in the Fabaceae, and estimates suggest that the tropical rain forest biome may account for up to $25 \%$ of natural terrestrial BNF (Cleveland et al. 1999). Second, empirical data describing natural $\mathrm{N}$ fixation rates in tropical forests are rare, and large-scale estimates of tropical $\mathrm{N}$ fixation are based on a handful of instantaneous, plotscale estimates extrapolated to the biome scale. Third, while $\mathrm{N}$ fixation is presumed to be high in tropical rain forests, a number of recent studies have questioned this conclusion (e.g., Gehring et al. 2005). Fourth, since the potential for substantial natural $\mathrm{N}$ fixation appears high in lowland tropical forests, further constraining $\mathrm{N}$ inputs via $\mathrm{N}$ fixation is a necessary next step in evaluating how human activities have altered the global $\mathrm{N}$ cycle. Finally, the study site in the Amazon Basin is well studied, and thus a wealth of empirically-derived biogeochemical data necessary for generating estimates of BNF using both the modeling and mass balance approaches were available.

\section{Methods}

Study sites

To generate both modeled and mass-balance estimates of $\mathrm{N}$ fixation, we synthesized data from several primary rain forest sites in central Rondônia in the Amazon Basin (Fig. 1). These were Fazenda (Ranch) Nova Vida $\left(10^{\circ} 30^{\prime} \mathrm{S}, 62^{\circ} 30^{\prime} \mathrm{W}\right)$, Rancho Grande $\left(10^{\circ} 18^{\prime} \mathrm{S}, 62^{\circ} 52^{\prime} \mathrm{W}\right)$, and a site in Santa Bárbara $\left(9^{\circ} 11^{\prime} \mathrm{S}, 63^{\circ} 07^{\prime} \mathrm{W}\right)$ (Fig. 1). Detailed descriptions of the sites can be found elsewhere (Kauffman et al. 1995; Neill et al. 1997; Germer et al. 2007), but all are in primary tropical forests, are similar topographically and climatologically, and soils at all the study sites are classified as Ultisols (Table 1). We also obtained data on legume abundance from a study conducted at the nearby Samuel Ecological Reserve in northern Rondônia (Martinelli et al. 2000). For the purposes of this analysis, data from these adjacent sites were
Fig. 1 Location of Rondônia and the primary forest study sites

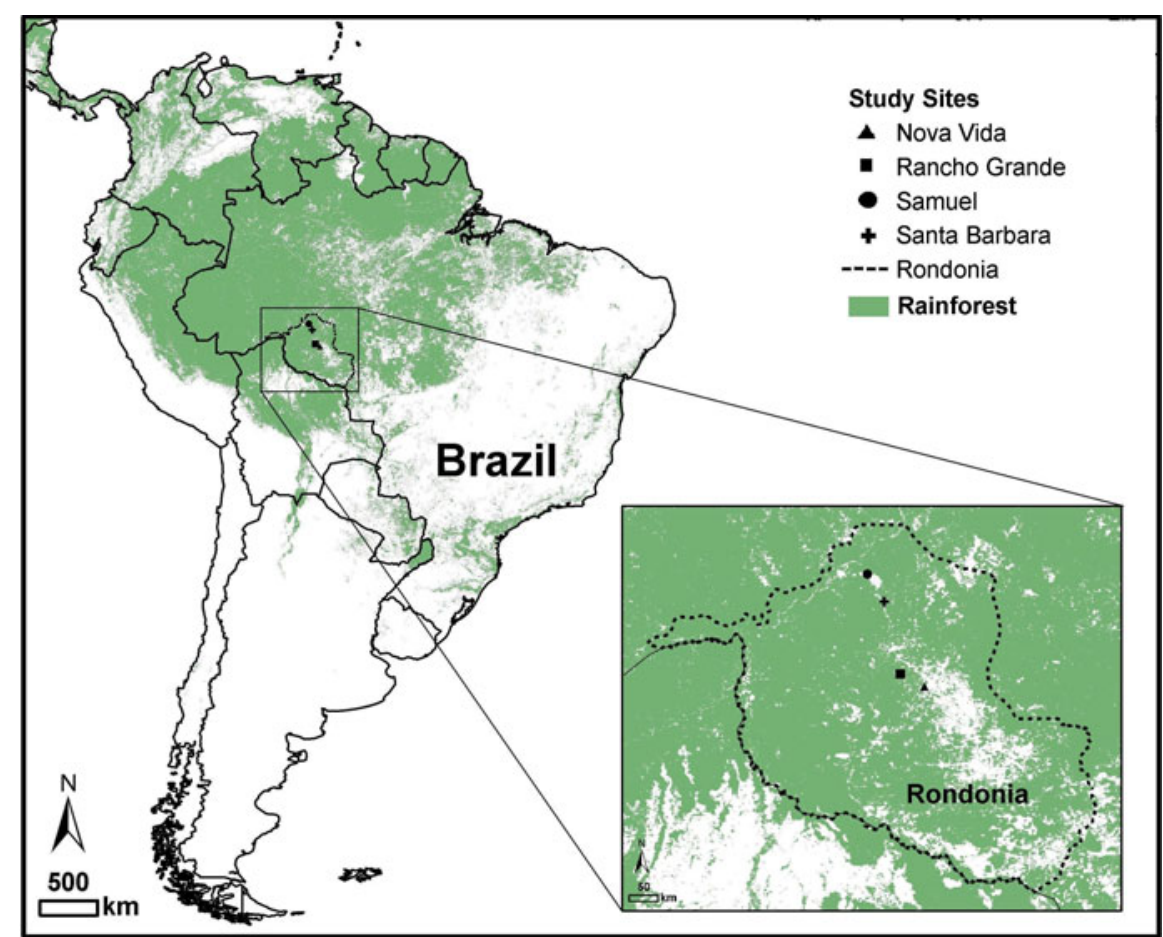


Table 1 Climatologic, topographic and edaphic characteristics of the study sites

\begin{tabular}{|c|c|c|c|c|}
\hline & \multicolumn{4}{|l|}{ Site } \\
\hline & Nova Vida & Rancho Grande & Santa Bárbara & Samuel Reserve \\
\hline Mean annual temperature $\left({ }^{\circ} \mathrm{C}\right)$ & 25 & 27 & 26 & NA \\
\hline Mean annual precipitation (mm) & 2200 & 2300 & 2100 & 2300 \\
\hline Dry season & May-Sept & July-Sept & June-Sept & June-Sept \\
\hline Elevation (m) & 150 & 143 & NA & NA \\
\hline Soil type & Ultisols & Ultisols & $\begin{array}{l}\text { Oxisols/ } \\
\text { Ultisols }\end{array}$ & Oxisols \\
\hline
\end{tabular}

combined to generate results that describe a single, representative primary forest site in Rondônia.

\section{Modeled estimates of BNF}

Several models have attempted to examine patterns and regulation of $\mathrm{N}$ fixation on land (Vitousek and Field 1999; Vitousek et al. 2002). Most recently, Houlton et al. (2008) applied the resource optimization paradigm (Rastetter et al. 2001; Wang et al. 2007) to simulate $\mathrm{N}$ fixation among diverse terrestrial ecosystems and at the global scale. This model, which is described in detail in Wang et al. (2007) and Houlton et al. (2008) and depicted in Fig. 2 consists of multiple pools of $\mathrm{C}, \mathrm{N}$ and $\mathrm{P}$ in soils and in $\mathrm{N}$-fixing and non-fixing plants, and fully couples carbon (C), $\mathrm{N}$ and phosphorus (P) interactions

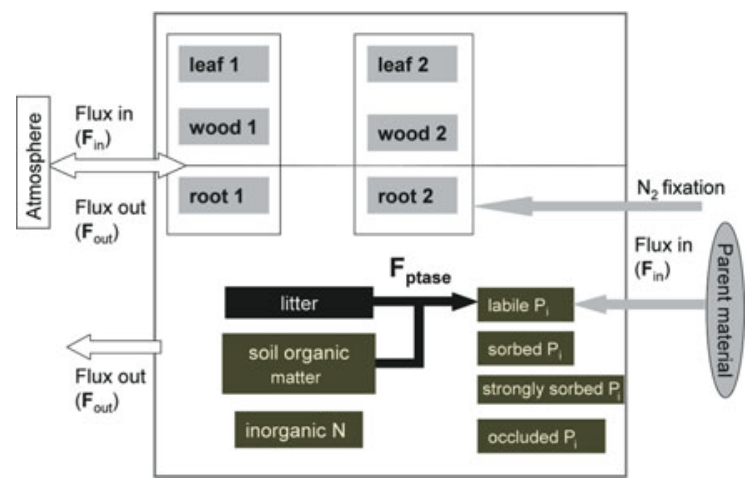

Fig. 2 Schematic diagram of the analytical model used in this analysis. The large square box represents the spatial domain of the Rondônia primary forest, within which plant pools (light grey boxes, one set that represents plants that fix $\mathrm{N}$ and another that does not) and corresponding litter and soil pools (dark grey boxes) exist. Exchanges between the atmosphere, hydrosphere, and geosphere are indicated by arrows. Biochemical $\mathrm{P}$ mineralization rate $\left(F_{\text {Ptase }}\right)$ represents the flow of organic $\mathrm{P}$ from litter to the labile P pool. Reproduced from Wang et al. (2007) by permission of the American Geophysical Union according to widely accepted conceptual models of ecosystem nutrient dynamics (Walker and Syers 1976; McGill and Cole 1981).

Briefly, $\mathrm{N}$-fixing and non $\mathrm{N}$-fixing plants are identical in the model, except for the capacity to fix N. Plants compete for light aboveground and nutrients belowground, with competitive outcomes proportional to net primary production (NPP) yield. In maximizing NPP, the model considers optimal strategies in acquiring $\mathrm{N}$ ( $\mathrm{N}$ uptake versus $\mathrm{N}$ fixation) and $\mathrm{P}$ (phosphatase enzymes versus uptake of microbially-mineralized $\mathrm{P}$ ), and in $\mathrm{C}$ allocation (e.g., to shoots versus roots) in a given environment and parameter space. To simulate the widely known energetic constraints to $\mathrm{N}$ fixation, the model assumes a cost of $10 \mathrm{~g}$ of $\mathrm{C}$ per $\mathrm{g}$ of $\mathrm{N}$ fixed (Gutschick 1981; Vitousek and Field 1999). Thus, while allocation of C is initially the same among fixers and non-fixers, the differential $\mathrm{C}$ cost of these two pathways ultimately modifies the investment in belowground pools. In addition, maximum achievable rates of $\mathrm{N}$ fixation are forced by an empirically derived relationship between nitrogenase activity and temperature (Houlton et al. 2008). For $\mathrm{P}$ acquisition, the model assumes a requirement of $15 \mathrm{~g}$ of $\mathrm{N}$ per $\mathrm{g}$ of plant $\mathrm{P}$ captured via phosphatase pathways (i.e., organic P-hydrolyzing enzymes), consistent with conceptual models and empirical studies (Olander and Vitousek 2000; Treseder and Vitousek 2001).

For our analysis, we parameterized the model using a combination of data from either Nova Vida or Santa Barbara (Table 2). The inputs to the model included monthly mean air temperature, NPP as estimated by the CASA model (Potter et al. 2001), and $\mathrm{N}$ and $\mathrm{P}$ inputs of $1.13 \mathrm{~g} \mathrm{~N} \mathrm{~m}^{-2}$ year $^{-1}$ (Table 5) and $0.002 \mathrm{~g} \mathrm{P} \mathrm{m}^{-2}$ year $^{-1}$, respectively (Houlton et al. 2008). The model was calibrated by scaling maximum uptake rates of $\mathrm{C}, \mathrm{N}$ and $\mathrm{P}$ until the 
Table 2 Carbon $(\mathrm{C})$ pools, nitrogen $(\mathrm{N})$ and phosphorus $(\mathrm{P})$ concentrations and other data used to parameterize the model

\begin{tabular}{|c|c|c|c|}
\hline Parameter & Value & Units & Reference \\
\hline \multicolumn{4}{|l|}{ C pools } \\
\hline Foliar biomass & 3.13 & $\mathrm{Mg} / \mathrm{ha}$ & Kauffman et al. (1995) \\
\hline Woody biomass & 66.35 & $\mathrm{Mg} / \mathrm{ha}$ & Kauffman et al. (1995) \\
\hline Root biomass & 6.22 & $\mathrm{Mg} / \mathrm{ha}$ & Kauffman et al. (1995) \\
\hline Standing litter biomass & 5.5 & $\mathrm{Mg} / \mathrm{ha}$ & Kauffman et al. (1995) \\
\hline Soil C & 87 & $\mathrm{Mg} / \mathrm{ha}$ & Hughes et al. (2002) \\
\hline \multicolumn{4}{|l|}{$\mathrm{N}$ concentrations } \\
\hline Foliar N & 23.32 & $\mathrm{mg} / \mathrm{g}$ & Kauffman et al. (1995) \\
\hline Wood N & 5.23 & $\mathrm{mg} / \mathrm{g}$ & Kauffman et al. (1995) \\
\hline Root N & 18.97 & $\mathrm{mg} / \mathrm{g}$ & Kauffman et al. (1995) \\
\hline Litter N & 18.91 & $\mathrm{mg} / \mathrm{g}$ & Kauffman et al. (1995) \\
\hline \multicolumn{4}{|l|}{ Soil N } \\
\hline Total & 0.58 & $\mathrm{mg} / \mathrm{g}$ & Hughes et al. (2002) \\
\hline Mineral & 3.1 & $\mu \mathrm{g} / \mathrm{g}$ & Garcia-Montiel et al. (2001) \\
\hline \multicolumn{4}{|l|}{$\mathrm{P}$ concentrations } \\
\hline Foliar P & 0.92 & $\mathrm{mg} / \mathrm{g}$ & Kauffman et al. (1995) \\
\hline Wood P & 0.16 & $\mathrm{mg} / \mathrm{g}$ & Kauffman et al. (1995) \\
\hline Root P & 0.50 & $\mathrm{mg} / \mathrm{g}$ & Kauffman et al. (1995) \\
\hline Litter P & 0.65 & $\mathrm{mg} / \mathrm{g}$ & Kauffman et al. (1995) \\
\hline \multicolumn{4}{|l|}{ Soil P } \\
\hline Labile P & 4.4 & $\mu \mathrm{g} / \mathrm{g}$ & Garcia-Montiel et al. (2000) \\
\hline Organic P & 13.8 & $\mu \mathrm{g} / \mathrm{g}$ & Garcia-Montiel et al. (2000) \\
\hline Sorbed P & 6.1 & $\mu \mathrm{g} / \mathrm{g}$ & Garcia-Montiel et al. (2000) \\
\hline Occluded P & 14.9 & $\mu \mathrm{g} / \mathrm{g}$ & Garcia-Montiel et al. (2000) \\
\hline Residual P & 28.0 & $\mu \mathrm{g} / \mathrm{g}$ & Garcia-Montiel et al. (2000) \\
\hline \multicolumn{4}{|l|}{ Fluxes } \\
\hline $\mathrm{N}$ deposition & 5.3 & $\mathrm{~kg} / \mathrm{ha}$ & Germer et al. (2007) \\
\hline Net primary production (NPP) & 1247 & $\mathrm{~g} / \mathrm{m}^{2} /$ year & Potter et al. (2001) \\
\hline \multicolumn{4}{|l|}{ Other } \\
\hline Leaf Area Index (LAI) & 4.6 & $\mathrm{~m}^{2} / \mathrm{m}^{2}$ & Potter et al. (2001) \\
\hline Legume abundance & 13 & $\%$ & Martinelli et al. (2000) \\
\hline Potential N-fixer abundance & 5.2 & $\%$ & This study \\
\hline
\end{tabular}

amount of soil $\mathrm{C}, \mathrm{N}$ and $\mathrm{P}$ at steady state agreed with the data in Table 2. The model was then run to steady state, providing an estimate of $\mathrm{N}$ fixation rates under quasi-equilibrium conditions.

Rates of symbiotic $\mathrm{N}$ fixation were modeled using the following equation:

$F_{\mathrm{N}, \mathrm{fix}}=v_{\mathrm{fix}} f_{\mathrm{fix}} \mathrm{C}_{\mathrm{fix}, \mathrm{r}}$

where, $v_{\text {fix }}$ is the rate of $\mathrm{N}_{2}$ fixed per unit of nodulated root $\left(\left[\mathrm{gN} \mathrm{gC}^{-1}\right]\right.$ year $\left.^{-1}\right), f_{\text {fix }}$ is the fraction of nodulated root biomass, and $C_{\mathrm{fix}, \mathrm{r}}$ is the total root $\mathrm{C}$ pool. The second two terms on the right hand side of (1) are simulated by the model, whereas $v_{\text {fix }}$ is a parameter that can be adjusted to force the model to known abundance patterns of symbiotic $\mathrm{N}$-fixers at a given site. This approach assumes that the biomass of fixers and non-fixers is proportional to their contributions to NPP; in addition, we assume that $f_{\text {fix }}$ is a long-term integrative (i.e., steady-state) mean, as opposed to considering fine-scale temporal dynamics in this parameter.

We estimated symbiotic N-fixer abundance in the Rondônia primary forest from empirically measured abundances of Fabaceae species in the forest at the Samuel Ecological Reserve (Samuel) (Martinelli et al. 2000) and from information on known nodulation 
patterns of species within the Fabaceae. Namely, legumes represent $13 \%$ of total tree species abundance in the Samuel forest (Martinelli et al. 2000). Seventyfive percent of the legumes surveyed at the site occupy genera within the Caesalpiniaceae subfamily, and $\sim 20 \%$ of the Caesalpiniaceae surveyed to date have the capacity to nodulate (Sprent 2005). We therefore estimate that potentially $\mathrm{N}$-fixing Caesalpiniaceae species represent $1.95 \%$ of the trees at Samuel. Species within the Mimosaceae make up the balance (25\%) of the legumes at Samuel. Data on nodulation of the Mimosaceae species at the site were unavailable, so we assumed that $100 \%$ of the Mimosaceae species at Samuel have the capacity to nodulate and fix N (representing $3.25 \%$ of the total species at Samuel). Assuming that species abundance is proportional to biomass, we estimate that a total of $5.2 \%$ of the biomass at Samuel consists of trees with the capacity to fix $\mathrm{N}$. Therefore, for our simulations of $\mathrm{N}$ fixation rates, we adjusted $v_{\text {fix }}$ until the modeled abundance of symbiotic N-fixers agreed with this measured estimate, holding all other parameters constant. For more information on the sensitivity of the model to input parameters, please refer to Wang et al. (2007).

\section{$\mathrm{N}$ balance estimates of $\mathrm{BNF}$}

If an ecosystem is at steady state with respect to $\mathrm{N}$, then $\mathrm{N}$ inputs via symbiotic BNF can be assessed from net differences between all other measured $\mathrm{N}$ inputs and outputs. Similar mass-balance approaches have be used successfully to generate nearly complete input-output budgets for non-gaseous elements in small watersheds (Likens and Borman 1995), and comprehensive ecosystem $\mathrm{N}$ balances have been estimated by quantifying $\mathrm{N}$ inputs, hydrologic $\mathrm{N}$ losses, $\mathrm{N}$ pools, $\mathrm{N}$ transformations and $\mathrm{N}$ fluxes (e.g., McDowell and Asbury 1994; Neill et al. 2001, 2006; Chaves et al. 2007).

While the assumption of steady state is implicit in this approach, we believe this is reasonable in this primary forest site. First, while atmospheric $\mathrm{N}$ deposition in this region is high relative to the Amazon as a whole (L. Lara, personal communication), this is a recent phenomenon (Germer et al. 2007). In addition, the site has remained free from catastrophic fires and other large-scale or long-term disturbances that would more fundamentally alter the $\mathrm{N}$ cycle and thus more seriously violate the steady state assumption.
$\mathrm{N}$ inputs

Together, symbiotic $\mathrm{N}$ fixation, free-living $\mathrm{N}$ fixation and atmospheric deposition are the dominant sources of external $\mathrm{N}$ to the forests of Amazon Basin. In some ecosystems, geological weathering can also contribute sizable N inputs (e.g., Dahlgren 1994). However, this is likely negligible in the Rondônia primary forest because the low- $\mathrm{N}$ parent materials that dominate the site have weathered significantly past the point at which local rocks contribute substantial nutrients (Sanchez et al. 1982).

We obtained estimates of bulk atmospheric (total $\mathrm{N})$ deposition at Rancho Grande from the literature. Next, compared to symbiotic $\mathrm{N}$ fixation, free-living $\mathrm{N}$ fixation can be measured with relative confidence using current methods. Free-living $\mathrm{N}$ fixation has been observed in multiple substrates including leaf litter, soil, decaying wood, and on plant leaves, and larger-scale rates have been estimated in a variety of ecosystems (Cleveland et al. 1999; Son 2001). Empirical measurements of free-living $\mathrm{N}$ fixationdefined here as any $\mathrm{N}$ fixation not occurring via a structured symbiotic relationship between Rhizobia and legume roots-were not available from any of the sites in Rondônia, and were therefore calculated from published estimates of free-living $\mathrm{N}$ fixation data obtained from a range of sites throughout the humid neotropics (Table 3). If multiple components of free-living $\mathrm{N}$ fixation were assayed at the same site (e.g., leaf litter, decaying wood), those values were added to generate a single estimate (Table 3). Similarly, if $\mathrm{N}$ fixation was assayed multiple times on the same substrate at the same site, we created a singlesite average of data. All free-living $\mathrm{N}$ fixation rate data used in our analyses were originally obtained using the acetylene reduction assay (Burns and Hardy 1975).

\section{$\mathrm{N}$ losses}

$\mathrm{N}$ can be lost from ecosystems via erosion, fire, or biomass removal, but gaseous emissions and export to streams are the principal mechanisms of $\mathrm{N}$ loss from primary tropical rain forests (Chestnut et al. 1999; Melillo et al. 2001; Markewitz et al. 2004; Neill et al. 2006). Hydrological $\mathrm{N}$ losses- $\mathrm{N}$ lost along the continuum from soils to streams-were calculated from the literature, with an emphasis on data obtained 
Table 3 Rates of freeliving $\mathrm{N}$ fixation in tropical forests. All rates $(\mathrm{kg} \mathrm{N}$ fixed $\mathrm{ha}^{-1}$ year $^{-1}$ ) were obtained using the acetylene reduction assay. Nitrogen fixation rate averages are provided for each substrate, and averages within each substrate compartment were added to generate the "total estimated flux" of $\mathrm{N}$ via free-living $\mathrm{N}$ fixation

Table 4 Summary of literature-derived $\mathrm{NO}$ and $\mathrm{N}_{2} \mathrm{O}$ emissions from primary tropical rain forests in Rondônia. Calculated averages for $\mathrm{NO}$ and $\mathrm{N}_{2} \mathrm{O}$ losses were added to generate the total estimated $\mathrm{N}$ trace gas flux estimate

\begin{tabular}{|c|c|c|c|}
\hline Substrate & Site & $\begin{array}{l}\text { Rate } \\
\left(\mathrm{kg} \mathrm{N} \mathrm{ha}^{-1} \text { year }^{-1}\right)\end{array}$ & Reference \\
\hline \multirow[t]{4}{*}{ Canopy epiphytes } & Columbia & 1.5 & Forman (1975) \\
\hline & Brazil & $<1$ & Jordan et al. (1983) \\
\hline & Costa Rica & 3 & Freiberg (1998) \\
\hline & Costa Rica & $<0.1$ & Reed et al. (2008) \\
\hline Estimated flux & & 1 & \\
\hline \multirow[t]{7}{*}{ Litter layer } & Brazil & 8 & Jordan et al. (1983) \\
\hline & Hawaii & 2.8 & Vitousek (1994) \\
\hline & Hawaii & $<1$ & Russell and Vitousek (1997) \\
\hline & Hawaii & 4.9 & Ley and D'Antonio (1998) \\
\hline & Hawaii & 1 & $\begin{array}{l}\text { Crews et al. (2000), Matzek } \\
\text { and Vitousek (2003) }\end{array}$ \\
\hline & Hawaii & 2.4 & Crews et al. (2001) \\
\hline & Costa Rica & 3.5 & Reed et al. (2007) \\
\hline Estimated flux & & 3 & \\
\hline \multirow[t]{3}{*}{ Soil } & Brazil & 1.3 & Sylvester-Bradley et al. (1980) \\
\hline & Brazil & 3 & Jordan et al. (1983) \\
\hline & Costa Rica & 3 & Reed et al. (2007) \\
\hline Estimated flux & & 2 & \\
\hline Total estimated flux & & 6 & \\
\hline
\end{tabular}

\begin{tabular}{llll}
\hline Trace gas losses & $\begin{array}{l}\text { Rate } \\
\left(\mathrm{kg} \mathrm{N} \mathrm{ha}^{-1} \mathrm{year}^{-1}\right)\end{array}$ & Season & Reference \\
\hline $\mathrm{NO}$ & 2.4 & & Garcia-Montiel et al. (2003) \\
& 2.2 & Wet & Steudler et al. (2002) \\
& 0.6 & Gry & Garcia-Montiel et al. (2001) \\
& 2.8 & & Neill et al. (2005) \\
& 1.4 & & \\
Estimated NO flux & 1.9 & & Garcia-Montiel et al. (2004) \\
$\mathrm{N}_{2} \mathrm{O}$ & 2.1 & Wet & Garcia-Montiel et al. (2001) \\
& 6.2 & Dry & Garcia-Montiel et al. (2001) \\
& 0.0 & Wet & Neill et al. (2005) \\
& 3.2 & Dry & Neill et al. (2005) \\
Estimated $\mathrm{N}_{2} \mathrm{O}$ flux & 2.0 & & \\
Total estimated $\mathrm{N}$ trace & 4.6 & & \\
gas flux & & &
\end{tabular}

from the forest at Rancho Grande. We estimated $\mathrm{N}$ losses from hydrologic fluxes leading from surface soils $(20 \mathrm{~cm})$ to streams $\left(8.7 \mathrm{~kg} \mathrm{~N} \mathrm{ha}^{-1}\right.$ year $\left.^{-1}\right)$ based on Chaves et al. (2009; Table 4). It is possible that deep soil storage or adsorption accounted for a portion of these losses, and we assumed that this $\mathrm{N}$ was not available to plants (representing a net loss of $\mathrm{N})$ and therefore had to be balanced by BNF. N losses as $\mathrm{NO}$ and $\mathrm{N}_{2} \mathrm{O}$ were estimated from published data obtained from the Rondônia sites (Table 4). Data collected multiple times at the same site were averaged to create a single $\mathrm{N}_{2} \mathrm{O}$ or NO flux (Table 4). 
As is the case with $\mathrm{N}$ fixation, direct measurements of gaseous soil $\mathrm{N}$ losses as $\mathrm{N}_{2}$ are hindered by methodological limitations (Davidson and Seitzinger 2006; Groffman et al. 2006). Soil $\mathrm{N}_{2} \mathrm{O}$ and NO fluxes likely represent two important $\mathrm{N}$ losses from most tropical rain forests (e.g., Matson and Vitousek 1990; Matson et al. 1999), but measured fluxes of NO and $\mathrm{N}_{2} \mathrm{O}$ still underestimate total gaseous $\mathrm{N}$ losses because they do not account for $\mathrm{N}_{2}$ efflux during denitrification. Measurements of $\mathrm{N}_{2}$ emissions from tropical forest soils are virtually nonexistent (and the true extent of gaseous $\mathrm{N}$ losses remain a major source of uncertainty in Amazon forest $\mathrm{N}$ budgets), but several studies highlight the potential for very high $\mathrm{N}_{2}$ losses (e.g., Houlton et al. 2006).

Thus, we estimated total $\mathrm{N}_{2} \mathrm{O}+\mathrm{N}_{2}$ production directly using a soil incubation experiment. Acetylene $\left(\mathrm{C}_{2} \mathrm{H}_{2}\right)$ blocks the reduction of $\mathrm{N}_{2} \mathrm{O}$ to $\mathrm{N}_{2}$ (Yoshinari and Knowles 1976; Tiedje 1982), and the difference between treatments (i.e., with or without $\mathrm{C}_{2} \mathrm{H}_{2}$ ) provides an estimate of the $\mathrm{N}$ released as $\mathrm{N}_{2}$ during denitrification (and hence total $\mathrm{N}$ trace gas losses, but see Groffman et al. (2006)). Twenty Rondônia forest soil samples obtained from the surface $(0-5 \mathrm{~cm})$ were sieved to $4 \mathrm{~mm}$, placed in airtight jars, and incubated under one of three conditions: (1) at ambient dry season moisture; (2) amended with $1.0 \mu \mathrm{g} \mathrm{NO}_{3}{ }^{-}-\mathrm{Ng}$ dry soil $^{-1}$ and water to field capacity; and (3) amended with $1.0 \mu \mathrm{g} \mathrm{NO}_{3}{ }^{-}-\mathrm{Ng}$ dry soil ${ }^{-1}$ and water to field capacity plus $10 \mathrm{kPa}$ acetylene. Nitrous oxide in the jars was periodically sampled using $20 \mathrm{ml}$ gastight syringes, and concentrations of $\mathrm{N}_{2} \mathrm{O}$ were measured on a gas chromatograph equipped with an electron capture detector (ECD; Shimadzu Mini-2, Shimadzu Corp, Kyoto, Japan). Fluxes were calculated as $\mathrm{N}_{2} \mathrm{O}$ produced per unit time and normalized per gram of dry soil. While this laboratory experiment did not reflect actual field conditions, it does indicate the potential for $\mathrm{N}_{2}$ emissions from soils at this site.

\section{Results}

Modeled estimates of BNF

Assuming that $5.2 \%$ of the biomass in the Rondônia primary forest site fixes $\mathrm{N}$ (See Methods), our model- based analysis of symbiotic $\mathrm{N}$ fixation (i.e., forcing symbiotic N-fixers' NPP to $5.2 \%$ of the total) suggests a symbiotic $\mathrm{N}$ fixation input of $6.8 \mathrm{~kg} \mathrm{~N} \mathrm{ha}^{-1}$ year $^{-1}$.

$\mathrm{N}$ balance estimates of $\mathrm{BNF}$

\section{$N$ inputs}

Empirical measurements indicate that bulk $\mathrm{N}$ deposition inputs to the region (Rancho Grande) are $5.3 \mathrm{~kg} \mathrm{~N}^{-1}$ year $^{-1}$, with inputs dominated by $\mathrm{NH}_{4}{ }^{+}$(Germer et al. 2007). We also estimate that free-living $\mathrm{N}$ fixation in tropical forest canopies, decomposing organic matter, and soils contribute an additional $6 \mathrm{~kg} \mathrm{~N} \mathrm{ha}^{-1}$ year $^{-1}$ to the Amazon Basin, including the Rondônia tropical forest site (range = 1-8 $\mathrm{kg} \mathrm{N} \mathrm{ha}^{-1}$ year $^{-1}$; Table 3 ). Because no single study accounted for all possible sources of free-living $\mathrm{N}$ fixation, we believe this value represents a conservative estimate. Thus we estimate total $\mathrm{N}$ inputs to the watershed (excluding symbiotic $\mathrm{N}$ fixation) of $11.3 \mathrm{~kg} \mathrm{~N} \mathrm{ha}^{-1}$ year $^{-1}$ via the combined processes of atmospheric deposition $\left(5.3 \mathrm{~kg} \mathrm{~N}^{-1}\right.$ year $\left.^{-1}\right)$ and free-living $\mathrm{N}$ fixation $\left(6.0 \mathrm{~kg} \mathrm{~N} \mathrm{ha}^{-1}\right.$ year $\left.^{-1}\right)$.

\section{$N$ losses}

The low pH (4.9) of the Nova Vida rain forest soils indicates that ammonia volatilization $(\mathrm{pKa}=9.3)$ is negligible. Losses of $\mathrm{N}$ via $\mathrm{NO}$ and $\mathrm{N}_{2} \mathrm{O}$ at the site are $4.5 \mathrm{~kg} \mathrm{~N}^{-1}$ year $^{-1}$. In our incubations, $\mathrm{N}_{2} \mathrm{O}$ fluxes with acetylene averaged $0.29 \pm 0.04 \mu \mathrm{g}$ $\mathrm{N}_{2} \mathrm{O}-\mathrm{N} \mathrm{h}^{-1}$, and $\mathrm{N}_{2} \mathrm{O}$ fluxes without acetylene averaged $0.14 \pm 0.04 \mu \mathrm{g} \mathrm{N}_{2} \mathrm{O}-\mathrm{N} \mathrm{h}^{-1}$. Thus, we estimate that $\mathrm{N}_{2}$ emissions equal losses as $\mathrm{N}_{2} \mathrm{O}$ (i.e., $2.6 \mathrm{~kg} \mathrm{~N} \mathrm{ha}^{-1}$ year $^{-1}$ ), resulting in a total gaseous loss of $7.1 \mathrm{~kg} \mathrm{~N} \mathrm{ha}^{-1}$ year $^{-1}$ (Tables 4,5 ).

We estimate a net decrease ( $\mathrm{N}$ loss) of $8.7 \mathrm{~kg} \mathrm{~N} \mathrm{ha}^{-1}$ year $^{-1}$ via hydrologic flowpaths from soil solution to groundwater (Chaves et al. 2009). Thus, we estimate total watershed $\mathrm{N}$ losses of $15.8 \mathrm{~kg} \mathrm{ha}^{-1}$ year $^{-1}$, which includes total $\mathrm{N}$ gas losses of $7.1 \mathrm{~kg} \mathrm{~N} \mathrm{ha}^{-1}$ year $^{-1}$, and total hydrologic flowpath losses of $8.7 \mathrm{~kg} \mathrm{~N} \mathrm{ha}^{-1}$ year $^{-1}$ (Chaves et al. 2009). Using the mass balance approach, we therefore estimate that symbiotic $\mathrm{N}$ fixation contributes $4.5 \mathrm{~kg} \mathrm{~N} \mathrm{ha}^{-1}$ year $^{-1}$ to the Rondônia site (Table 5). 
Table 5 Estimated $\mathrm{N}$ fluxes in the Rondônia primary forest calculated using the $\mathrm{N}$ balance and modeling approaches, compared to the bottom-up estimate of Cleveland et al. (1999). N balance data represent the mean of published or derived values, with potential ranges based on variation among individual components in Tables 3 and 4 (in parentheses). Unless otherwise noted, data are reported with units of kg N ha ${ }^{-1}$ year $^{-1}$

\begin{tabular}{lll}
\hline Source & External input & External output \\
\hline$N$ balance estimate & & \\
$\mathrm{N}$ inputs & & \\
Precipitation (bulk) & 5.3 & \\
Weathering (geological) & 0 & \\
$\mathrm{~N}$ fixation (free-living) & $6(2.4-14)$ & \\
Total estimated N inputs & $11.3(7.7-19.3)$ & \\
$\mathrm{N}$ losses & & $2.6(2.0-6.2)$ \\
Gaseous N losses & & $1.9(0.6-2.8)$ \\
$\quad \mathrm{N}_{2} \mathrm{O}$ & & 2.6 \\
$\quad \mathrm{NO}$ & & $7.1(5.2-11.6)$ \\
$\quad \mathrm{N}_{2}$ & & 8.7 \\
Total gaseous N losses & & $15.8(13.9-20.3)$ \\
Deep soil/hydrologic flowpath $\mathrm{N}$ losses & & \\
Total estimated N losses & 4.5 & \\
Symbiotic N fixation & & \\
Modeled estimate & & \\
Simulated symbiotic N fixation & & \\
Databased estimate & & \\
Range N fixation (Cleveland et al. 1999) & & \\
Mean N fixation (Cleveland et al. 1999) & & \\
\hline
\end{tabular}

\section{Discussion}

We used two independent, indirect approaches to estimate symbiotic $\mathrm{N}$ fixation in the forest site in Rondônia, with remarkably consistent results (Table 5). Our analysis suggests rates of BNF in this tropical rain forest site (i.e., $4-7 \mathrm{~kg} \mathrm{~N} \mathrm{ha}^{-1}$ year $^{-1}$ ) that are lower than existing estimates for the tropical forest biome as a whole [e.g., $15-53 \mathrm{~kg} \mathrm{~N} \mathrm{ha}^{-1}$ year $^{-1}$ (Cleveland et al. 1999), $25 \mathrm{~kg} \mathrm{~N}^{-1}$ year $^{-1}$ (Houlton et al. 2008)] (see Table 5). This makes sense: the Rondônia site occupies the dry end of the rainfall spectrum for tropical rain forests and the abundance of $\mathrm{N}$-fixing legumes is relatively low compared to "average" Amazonian conditions (ter Steege et al. 2006). In wetter sites with more rapid $N$ cycling rates and higher potential $\mathrm{N}$ losses, BNF rates may be significantly higher than those estimated here; without significant inputs of new $\mathrm{N}$ via $\mathrm{BNF}$, high $\mathrm{N}$ losses would quickly deplete the $\mathrm{N}$ pools in productive, mature rain forest sites. In addition, relatively high $\mathrm{N}$ inputs via atmospheric deposition in the Rondônia site may actually be down-regulating current $\mathrm{N}$ fixation rates (Vitousek et al. 2002).
Our analysis also highlights the potential for $\mathrm{N}$-fixer abundance patterns to inform fluxes of $\mathrm{N}$ fixation at ecosystem scales. By forcing our model to field estimates for $\mathrm{N}$-fixer abundance in the Rondônia site, we found strong agreement between symbiotic $\mathrm{N}$ fixation rates_-based on modeling — and the "missing $\mathrm{N}$ " in our watershed-based on $\mathrm{N}$ flux estimates. This suggests an intriguing possibility: that putative $\mathrm{N}$-fixer abundance data, coupled with modeling, may be used to improve quantitative estimates of $\mathrm{N}$ fixation at large geographic scales. Although abundance data are not available for all (or even most) watershed sites, they are much easier to generate than many direct flux measurements. We suggest that this approach could be applied at other sites to examine potential connections between fixation and abundance patterns of putative $\mathrm{N}$-fixers in the tropics.

While these results illustrate the potential utility of indirect approaches for constraining estimates of BNF at the watershed (and perhaps larger) scales, each approach has limitations that must be considered when interpreting the results. In terms of the model, there is an implicit assumption that we have sufficient 
understanding of controls over $\mathrm{N}$ fixation to justify reasonable predictions using calibrated simulations. However, the costs of $\mathrm{N}$ fixation and $\mathrm{P}$ acquisition in the model are estimated and could benefit from additional field-studies and tests; the mechanisms regulating these "costs" are critical for accurately predicting rates of $\mathrm{N}$ fixation rates in terrestrial ecosystems (Vitousek and Field 1999; Rastetter et al. 2001; Houlton et al. 2008). Moreover, controls such as trace metal availability (Barron et al. 2008) and herbivory (Vitousek and Howarth 1991) are not currently incorporated in the model; future work demonstrating the importance of these types of controls on fixation may help to advance modeling analyses further.

Similar to the model, there are uncertainties in the $\mathrm{N}$ balance approach that could lead to systematic errors in estimates of symbiotic $\mathrm{N}$ fixation. First, direct field-based measurements of $\mathrm{N}_{2}$ fluxes do not exist, though $\mathrm{N}_{2}$ is likely to account for considerable losses of gaseous $\mathrm{N}$ from tropical forests (Robertson and Tiedje 1988; Houlton et al. 2006). In our lab assays, measured $\mathrm{N}_{2}$ losses were approximately equal to those as $\mathrm{N}_{2} \mathrm{O}$ (Fig. 3). However, high spatial and temporal variability in $\mathrm{N}_{2}$ versus $\mathrm{N}_{2} \mathrm{O}$ production during denitrification emphasizes the need to comprehensively assess these ratios (using $\mathrm{C}_{2} \mathrm{H}_{2}$, for

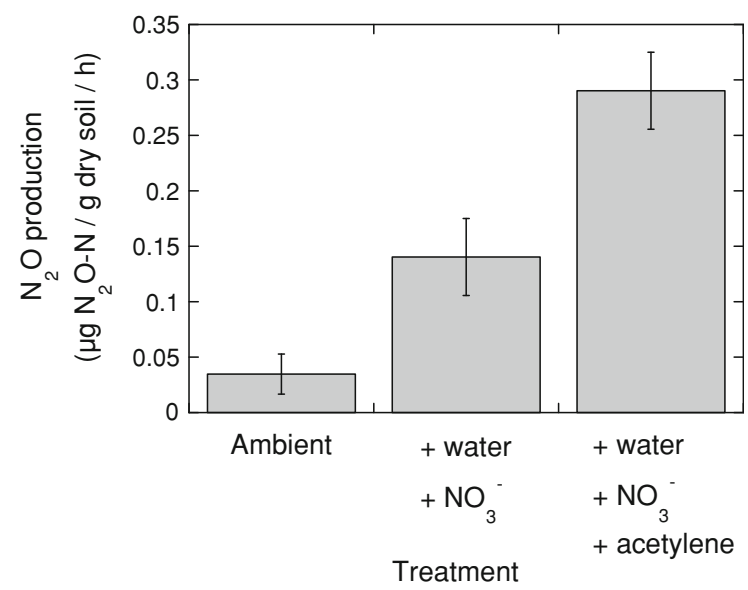

Fig. 3 Results of a laboratory incubation using soil from a primary forest in Rondônia. Treatments were: (1) soil incubated at ambient dry season moisture (ambient); (2) soil amended with $1.0 \mu \mathrm{g} \mathrm{NO}_{3}{ }^{-}-\mathrm{N} \mathrm{g}^{-1}$ dry soil and water to field capacity (+ water $+\mathrm{NO}_{3}{ }^{-}$); and (3) soil amended with $1.0 \mu \mathrm{g} \mathrm{NO}_{3}{ }^{-}-\mathrm{N} \mathrm{g}^{-1}$ dry soil and water to field capacity plus $10 \mathrm{kPa}$ acetylene $\left(+\right.$ water $+\mathrm{NO}_{3}{ }^{-}+$acetylene). Error bars are $\pm 1 \mathrm{SE}$ example) in both space and time, which remains another major challenge to biogeochemistry (Groffman et al. 2006). Next, the "deep soil/hydrologic flowpath N" term (Table 5) presents a dilemma for calculating total ecosystem $\mathrm{N}$ losses. Based on data collected at Rancho Grande, we estimate potential maximum $\mathrm{N}$ losses via hydrological flowpaths of $8.7 \mathrm{~kg} \mathrm{~N}^{-1}$ year $^{-1}$ (Table 5). Of that total, we estimate that $1.5 \mathrm{~kg} \mathrm{~N}^{-1}$ year $^{-1}$ is exported in streams. Of the remaining $7.2 \mathrm{~kg} \mathrm{~N} \mathrm{ha}^{-1}$ year $^{-1}$, we assume that some is lost via denitrification in zones not systematically sampled in soil trace gas studies (e.g., riparian areas) or via abiotic storage in deep soils. However, while root biomass is typically concentrated at soil depths above $1 \mathrm{~m}$, any plant $\mathrm{N}$ uptake via roots at depths $>1 \mathrm{~m}$ would move our mass-balance derived $\mathrm{N}$ loss estimate (and hence our $\mathrm{N}$ fixation estimate) downward. Finally, an assumption of steady state (with respect to $\mathrm{N}$ ) is implicit in the mass balance approach. In the Rondônia site, we believe this assumption is probably valid, but in recently disturbed sites or sites with a long history of chronic $\mathrm{N}$ deposition, for example, the steady state assumption may not be, thus limiting the utility of the mass balance approach.

In the decade since Cleveland et al. (1999) highlighted both the potential magnitude and uncertainty of tropical forest BNF, little progress has been made improving our understanding of the process. Doing so has become increasingly important, as human activities are now fundamentally altering the $\mathrm{N}$ cycle in many tropical forests (Martinelli et al. 2006). More accurate direct estimates of BNF will only be achieved when we overcome methodological limitations of measuring $\mathrm{N}$ fixation, just as more robust watershed-level estimates of $\mathrm{N}$ losses require improved methods for measuring gaseous $\mathrm{N}$ fluxes from soils and along hydrologic flowpaths. However, in the absence of a direct method for measuring symbiotic $\mathrm{N}$ fixation, we suggest that employing a strategy that combines modeling and empirical techniques-including analyses of natural abundance ${ }^{15} \mathrm{~N}$ pools (see Houlton et al. 2006), potential symbiotic $\mathrm{N}$-fixer abundances (e.g., Martinelli et al. 2000), freeliving $\mathrm{N}$ fixation rates (e.g., Reed et al. 2007), trace gas fluxes (e.g., Garcia-Montiel et al. 2003), and N losses via hydrologic pathways (e.g., Chaves et al. 2007) — in a series of small watersheds and in a range of biome types-offers an opportunity to further 
reduce uncertainties surrounding rates of and controls over BNF. We view the application of indirect methods to estimate $\mathrm{N}$ fixation as a useful bridge to the day when direct measurements of BNF at multiple scales are possible.

Acknowledgments We are grateful to the steering committee of the International Nitrogen Initiative, the organizers of the fourth Annual Nitrogen Conference, and to the Brazilian Government for funding. We also thank N. Ascarrunz, A. Austin, R. Boddey, J. Chaves, E. Davidson, C. Gehring, R. Howarth, E. Medina, J. Sprent, and the other participants of Working Group 1 for insightful discussions during the workshop and while writing this manuscript, Edith Bai for assistance with figure production, and Josh Schimel and one anonymous reviewer for providing a number of comments that improved the manuscript. We acknowledge and are grateful for financial support from the Andrew W. Mellon Foundation (C.C. and B.H.), the National Science Foundation (NSF DEB0515744 to C.C. and A.T. and DEB-0315656 to C.N.), and the NASA LBA Program (NCC5-285 to C.N.).

Open Access This article is distributed under the terms of the Creative Commons Attribution Noncommercial License which permits any noncommercial use, distribution, and reproduction in any medium, provided the original author(s) and source are credited.

\section{References}

Allen O, Allen E (1981) The Leguminosae. University of Wisconsin Press, Madison

Barron AR, Wurtzburger N, Bellenger JP, Kraepiel AML, Wright J, Hedin LO (2008) Molybdenum limitation of asymbiotic nitrogen fixation in tropical forest soils. Nat Geosci 2:42-45

Binkley D, Ice GG, Kaye J, Williams CA (2004) Nitrogen and phosphorus concentrations in forest streams of the United States. J Am Water Resour Assoc 40:1277-1291

Burns RC, Hardy RWF (1975) Nitrogen fixation in bacteria and higher plants. Springer-Verlag, Berlin

Chaves J, Neill C, Germer S, Neto S, Krusche A, Elsenbeer H (2007) Land management impacts on runoff sources in small Amazon watersheds. Hydrol Process. doi:101002. 1002/hyp.6803

Chaves J, Neill C, Germer S, Neto SG, Krusche AV, Bonilla AC, Elsenbeer H (2009) Nitrogen transformations in flow paths leading from soils to streams in Amazon forest and pasture. Ecosystems. doi:10.1007/s10021-009-9270-4

Chestnut TJ, Zarin DJ, McDowell WH, Keller M (1999) A nitrogen budget for late-successional hillslope tabonuco forest, Puerto Rico. Biogeochemistry 46:85-108

Cleveland CC, Townsend AR, Schimel DS, Fisher H, Howarth RW, Hedin LO, Perakis SS, Latty EF, von Fischer JC, Elseroad A, Wasson MF (1999) Global patterns of terrestrial biological nitrogen $\left(\mathrm{N}_{2}\right)$ fixation in natural ecosystems. Global Biogeochem Cycles 13:623-645
Cramer W, Kicklighter DW, Bondeau A, Moore B III, Churkina G, Nemry B, Ruimy A, Schloss AL, Participants of "Potsdam'95" (1999) Comparing global models of terrestrial net primary productivity (NPP): overview and key results. Glob Change Biol 5(Suppl 1):1-15

Crews TE, Farrington H, Vitousek PM (2000) Changes in asymbiotic, heterotrophic, nitrogen fixation on leaf litter of Metrosideros polymorpha with long-term ecosystem development in Hawaii. Ecosystems 3:386-395

Crews TE, Kurina LM, Vitousek PM (2001) Organic matter and nitrogen accumulation and nitrogen fixation during early ecosystem development in Hawai'i. Biogeochemistry 52:259-279

Dahlgren RA (1994) Soil acidification and nitrogen saturation from weathering of ammonium-bearing rock. Nature 368:838-841

Davidson EA, Seitzinger S (2006) The enigma of progress in denitrification research. Ecol Appl 16:2057-2063

Forman RTT (1975) Canopy lichens with blue-green algae: a nitrogen source in a Columbian rain forest. Ecology 56:1176-1184

Freiberg E (1998) Microclimatic parameters influencing nitrogen fixation in the phyllosphere of a Costa Rican premontane rain forest. Oecologia 17:9-18

Galloway JN, Aber JD, Erisman JW, Seitzinger SP, Howarth RW, Cowling EB, Cosby BJ (2003) The nitrogen cascade. Bioscience 53:341-356

Galloway JN, Dentener FJ, Capone DG, Boyer EW, Howarth RW, Seitzinger SP, Asner GP, Cleveland CC, Green PA, Holland EA, Karl DM, Michaels AF, Porter JH, Townsend AR, Vörösmarty CJ (2004) Nitrogen cycles: past, present, and future. Biogeochemistry 70:153-226

Garcia-Montiel DC, Neill C, Melillo J, Thomas S, Steudler P, Cerri C (2000) Soil phosphorus transformations following forest clearing for pasture in the Brazilian Amazon. Soil Sci Soc Am J 64:1792-1804

Garcia-Montiel DC, Steudler PA, Piccolo MC, Melillo JM, Neill C, Cerri CC (2001) Controls on soil nitrogen oxide emissions from forest and pastures in the Brazilian Amazon. Global Biogeochem Cycles 15:1021-1030

Garcia-Montiel DC, Steudler PA, Piccolo MC, Neill C, Melillo JM, Cerri CC (2003) Nitrogen oxide emissions following wetting of dry soil in forest and pastures in Rondônia, Brazil. Biogeochemistry 64:319-336

Garcia-Montiel DC, Melillo JM, Steudler PA, Tian H, Neill C, Kicklighter DW, Feigl B, Piccolo BM, Cerri C (2004) Emissions of $\mathrm{N}_{2} \mathrm{O}$ and $\mathrm{CO}_{2}$ from terra firme forests in Rondônia, Brazil. Ecol Appl 14:S214-S220

Gehring C, Vlek PLG, de Souza LAG, Denich M (2005) Biological nitrogen fixation in secondary regrowth and mature rainforest of central Amazonia. Agric Ecosyst Environ 111:237-252

Germer S, Neill C, Krusche AV, Gouveia SC, Elsenbeer H (2007) Seasonal and within-event dynamics of rainfall and throughfall chemistry in an open tropical rainforest in Rondônia, Brazil. Biogeochemistry 86:155-174

Groffman PM, Altabet MA, Böhlke JK, Butterbach-Bahl K, David MB, Firestone MK, Giblin AE, Kana TM, Nielson LP, Voytek MA (2006) Methods for measuring denitrification: diverse approaches to a difficult problem. Ecol Appl 16:2091-2122 
Gutschick VP (1981) Evolved strategies in nitrogen acquisition by plants. Am Nat 18:607-637

Houlton BZ, Sigman DM, Hedin LO (2006) Isotopic evidence for large gaseous nitrogen losses from tropical rainforests. Proc Natl Acad Sci USA 103:8745-8750

Houlton BZ, Sigman DM, Schuur EAG, Hedin LO (2007) A climate-driven switch in plant nitrogen acquisition within tropical forest communities. Proc Natl Acad Sci USA 104:8902-8906

Houlton BZ, Wang YY, Vitousek PM, Field CB (2008) A unifying framework for di-nitrogen fixation in the terrestrial biosphere. Nature 454:327-330

Hughes RF, Kauffman JB, Cummings DL (2002) Dynamics of aboveground and soil carbon and nitrogen stocks and cycling of available nitrogen along a land-use gradient in Rondônia, Brazil. Ecosystems 5:244-259

Jordan CW, Caskey W, Escalante G, Herrera R, Montagnini F, Todd R, Uhl C (1983) The nitrogen cycle in a 'Terra Firme' rain forest on Oxisol in the Amazon Territory of Venezuela. Plant Soil 67:325-332

Kauffman JB, Cummings DL, Ward DE, Babbitt R (1995) Fire in the Brazilian Amazon: 1. Biomass, nutrient pools, and losses in slashed primary forests. Oecologia 104:397-408

Ley RE, D'Antonio CM (1998) Exotic grass invasion alters potential rates of $\mathrm{N}$ fixation in Hawaiian woodlands. Oecologia 113:179-187

Likens G, Bormann F (1995) Biogeochemistry of a forested ecosystem, 2nd edn. Springer-Verlag, New York

Markewitz D, Davidson E, Moutinho P, Nepstad D (2004) Nutrient loss and redistribution after forest clearing on a highly weathered soil in Amazonia. Ecol Appl 14: S177-S199

Martinelli LA, Almeida S, Brown IF, Moreira MZ, Victoria RL, Filoso S, Ferreira CAC, Thomas WW (2000) Variation in nutrient distribution and potential nutrient losses by selective logging in a humid tropical forest of Rondônia, Brazil. Biotropica 32:597-613

Martinelli LA, Howarth RW, Cuevas E, Filoso S, Austin AT, Donoso L, Huszar V, Keeney D, Lara LL, Llerena C, McIssac G, Medina E, Ortiz-Zayas J, Scavia D, Schindler DW, Soto D, Townsend A (2006) Sources of reactive nitrogen affecting ecosystems in Latin America and the Caribbean: current trends and future perspectives. Biogeochemistry 79:3-24

Matson PA, Vitousek PM (1990) Ecosystem approach to a global nitrous oxide budget. Bioscience 40:667-672

Matson PA, McDowell WH, Townsend AR, Vitousek PM (1999) The globalization of $\mathrm{N}$ deposition: ecosystem responses in tropical ecosystems. Biogeochemistry 46: $67-83$

Matzek V, Vitousek PM (2003) Nitrogen fixation in bryophytes, lichens, and decaying wood along a soil-age gradient in Hawaiian montane rain forest. Biotropica 35:12-19

McDowell W, Asbury C (1994) Export of carbon, nitrogen and major ions from three tropical montane watersheds. Limnol Oceanogr 39:111-125

McGill WB, Cole CV (1981) Comparative aspects of cycling of organic $\mathrm{C}, \mathrm{N}, \mathrm{S}$, and $\mathrm{P}$ through soil organic matter. Geoderma 26:267-286

Melillo JM, Steudler PA, Feigl BG, Neill C, Garcia D, Piccolo MC, Cerri CC, Tian H (2001) Nitrous oxide emissions from forests and pastures of various ages in the Brazilian Amazon. J Geophys Res 106:34179-34188

Neill C, Melillo JM, Steudler PM, Cerri CC, de Moraes JFL, Piccolo MC, Brito M (1997) Soil carbon and nitrogen stocks following forest clearing for pasture in the southwestern Brazilian Amazon. Ecol Appl 7:1216-1225

Neill C, Deegan LA, Thomas SM, Cerri CC (2001) Deforestation for pasture alters nitrogen and phosphorus in small Amazonian Streams. Ecol Appl 11:1817-1828

Neill C, Steudler PA, Garcia-Montiel DC, Melillo JM, Feigl BJ, Piccolo MC, Cerri CC (2005) Rates and controls of nitrous oxide and nitric oxide emissions following conversion of forest to pasture in Rondônia. Nutr Cycl Agroecosyst 71:1-15

Neill C, Piccolo MC, Cerri CC, Steudler PA, Melillo JM (2006) Soil solution and nitrogen oxide losses during clearing of lowland Amazon forest for cattle pasture. Plant Soil 281:233-245

Olander LP, Vitousek PM (2000) Regulation of soil phosphatase and chitinase activity by $\mathrm{N}$ and $\mathrm{P}$ availability. Biogeochemistry 49:175-190

Potter C, Davidson E, Nepstad D, Reis de Carvalho C (2001) Ecosystem modeling and dynamica effects of deforestation on trace gas fluxes in Amazon tropical rain forests. For Ecol Manage 152:97-117

Rastetter EB, Vitousek PM, Field C, Shaver GR, Herbert D, Agren GI (2001) Resource optimization and symbiotic nitrogen fixation. Ecosystems 4:369-388

Reed SC, Cleveland CC, Townsend AR (2007) Controls over leaf litter and soil nitrogen fixation in two lowland tropical rain forests. Biotropica 39:585-592

Reed SC, Cleveland CC, Townsend AR (2008) Tree species control rates of free-living nitrogen fixation in a tropical rain forest. Ecology 89:2924-2934

Robertson GP, Tiedje JM (1988) Deforestation alters denitrification in a lowland tropical rain forest. Nature 336:756-759

Russell AE, Vitousek PM (1997) Decomposition and potential nitrogen fixation in Dicranopteris linearis litter on Mauna Loa, Hawai'i. J Trop Ecol 13:579-594

Sanchez PA, Bandy DE, Villachica JH, Nicholaides JJ (1982) Amazon Basin soils: management for continuous crop production. Science 216:821-827

Schulze ED (1989) Air pollution and forest decline in a spruce (Picea abies) forest. Science 244:776-782

Son Y (2001) Non-symbiotic nitrogen fixation in forest ecosystems. Ecol Res 16:183-196

Sprent JI (2005) Nodulated legume trees. In: Werner D, Newton WE (eds) Nitrogen fixation in agriculture, forestry and the environment. Springer, The Netherlands

Sprent JI, Parsons P (2000) Nitrogen fixation in legume and non-legume trees. Field Crops Res 65:183-196

Steudler PA, Garcia-Montiel DC, Piccolo MC, Neill C, Melillo JM, Feigl BJ, Cerri CC (2002) Trace gas responses of tropical forest and pasture soils to $\mathrm{N}$ and $\mathrm{P}$ fertilization. Global Biogeochem Cycles 16(2), 1023. doi:10.1029/2001 GB001394

Sylvester-Bradley R, De Oliviera LA, De Podesta Filho JA, St. John TV (1980) Nodulation of legumes, nitrogenase activity of roots, and occurrence of nitrogen fixing Azospirillum spp. in representative soils of Central Amazonia. Agro-Ecosystems 6:249-266 
ter Steege $\mathrm{H}$ et al (2006) Continental-scale patterns of canopy tree composition and function across Amazonia. Nature 443:444-447

Tiedje JM (1982) Denitrification. In: Page AL, Miller RH, Keeney DR (eds) Methods of soil analysis, part 2. American Society of Agronomy, Madison

Treseder KK, Vitousek PM (2001) Effects of nutrient availability on investment in acquisition of $\mathrm{N}$ and $\mathrm{P}$ in Hawaiian rain forests. Ecology 82:946-954

Vitousek PM (1994) Potential nitrogen fixation during primary succession in Hawai'i Volcanoes National Park. Biotropica 26:234-240

Vitousek PM, Mooney HA, Lubchenco J, Melillo JM (1997) Human domination of earth's ecosystems. Science 277: 494-499

Vitousek PM, Field CB (1999) Ecosystem constraints to symbiotic nitrogen fixers: a simple model and its implications. Biogeochemistry 46:179-202

Vitousek PM, Howarth RW (1991) Nitrogen limitation on land and sea: how can it occur? Biogeochemistry 13:87-115
Vitousek PM, Cassman K, Cleveland CC, Crews T, Field CB, Grimm NB, Howarth RW, Marino R, Martinelli LA, Rastetter E, Sprent JI (2002) Towards an ecological understanding of biological nitrogen fixation. Biogeochemistry 57(58): $1-45$

Walker TW, Syers JK (1976) The fate of phosphorus during pedogenesis. Geoderma 15:1-19

Wang YP, Houlton BZ, Field CB (2007) A model of biogeochemical cycles of carbon, nitrogen, and phosphorus including symbiotic nitrogen fixation and phosphatase production. Global Biogeochem Cycles 21. doi:10.1029/ 2006GB002797

Warembourg FR (1993) Nitrogen fixation in soil and plant systems. In: Knowles R, Blackburn TH (eds) Nitrogen isotope techniques. Academic Press, San Diego

Yoshinari T, Knowles R (1976) Acetylene inhibition of nitrous oxide reduction by denitrifying bacteria. Biophys Res Commun 69:705-710 